\title{
New diagnostic test for high risk of breast cancer in Poland
}

\author{
B Gorski
}

From Annual Conference on Hereditary Cancers 2009

Szczecin, Poland. 10-11 December 2009

It is a primary goal in clinical cancer genetics to identify in a population the full range of mutant alleles that predispose to breast cancer (or to another cancer) and then to offer a rapid and inexpensive genetic assay to test for these alleles in a single setting. Many challenges are raised by this approach.. The genetic test must be accurate, rapid and cost effective. If a disease-associated mutation is found, presymptomatic testing of other family members for the specific mutation is possible. In Poland the three founder mutations in BRCA1 (C61G, 4153delA, 5382insC) account for $86 \%$ of all BRCA1 and BRCA2 mutations. Mutations in BRCA2 are relatively rare in Poland and no founder BRCA2 mutations have been identified. Several other rare mutations in the BRCA1/2 genes have been found in Polish families with occurrence of hereditary breast and ovarian cancers. Application of Sequenom mutation detection platform, critically improved screening of broad Polish BRCA1/2 genes mutations spectrum. We have developed diagnostic test focused on 25 Polish recurrent BRCA1/2 genes mutations. Mutation detection method was based on automated MALDI-TOF mass spectrometry in Sequenom MassArray ${ }^{\mathrm{TM}}$ system using iPLEX GOLD assay reactions that ends after a Single Base Extension.

Submit your next manuscript to BioMed Central and take full advantage of:

- Convenient online submission

- Thorough peer review

- No space constraints or color figure charges

- Immediate publication on acceptance

- Inclusion in PubMed, CAS, Scopus and Google Scholar

- Research which is freely available for redistribution 